\title{
Open-access journal hits rocky times
}

The Public Library of Science (PLoS), the flagship publisher for the open-access publishing movement, faces a looming financial crisis. An analysis of the company's accounts, obtained by Nature, shows that the company falls far short of its stated goal of quickly breaking even. In an attempt to redress its finances, PLoS will next month hike the charge for publishing in its journals from US $\$ 1,500$ per article to as much as $\$ 2,500$.

Subscription-based journals recover much of the costs of peer review and editing - and in the case of commercial publishers such as Nature Publishing Group, make some of their profits - by charging for access to their products. But the PLoS journals, the first of which launched in 2003, adhere instead to an 'author pays' open-access model: costs are recovered by charging authors, and papers are made available free of charge to the end-user.

The publisher's premiere titles, PLoS Biology and PLOS Medicine, are intended to compete on quality with high-ranking weekly subscription journals such as Nature, Science and The New England Journal of Medicine. An equal goal was to show that the economics of author pays' could be made to work, by making PLoS financially sustainable.

But although PLoS Biology has achieved an impact factor of 14.7, a more than respectable score for a relatively new journal, an analysis of PLoS's accounts shows that the financial side of the business looks less rosy. As a US non-profit charity, PLoS must file its annual accounts to the Internal Revenue Service. Nature consulted these via GuideStar.org, a database that contains information on 1.5 million US non-profit organizations.

The figures show that PLoS lost almost $\$ 1$ million last year. Moreover, its total income from fees and advertising currently covers just $35 \%$ of its total costs. And although this income is increasing - from $\$ 0.75$ million in 2003-04 to $\$ 0.9$ million in 2004-05 — it lags far behind spending, which has soared from $\$ 1.5$ million to around $\$ 5.5$ million over the past three years.

To stay afloat, the firm continues to rely on the philanthropic grants that launched the project: $\$ 9$ million from the Gordon and Betty Moore Foundation and \$4 million from the Sandler Family Supporting Foundation, both based in San Francisco (see graphic). These covered $65 \%$ of the company's operating costs last year, but are running out: at the end oflast September, PLoS had assets of $\$ 3,393,265$.

${ }^{\circ}$ We will continue to rely on philanthropic grant support for the foreseeable future," says Mark Patterson, director of publishing at PLOS's UK office in Cambridge, and "possibly always". Patterson adds that he is hopeful that the Sandler Foundation will provide more grants.

${ }^{\alpha}$ This demonstrates once again the fragility of the author-pays model," says David Worlock, chairman of the London-based publishing consultancy Electronic Publishing Services. (Worlock has worked with a number of publishing companies including Nature Publishing Group.) "It's a real giveaway if they are now saying that they will always need some philanthropic funding."

But Patterson points out that PLoS launched most of its journals recently, and that income from these publications is only beginning to accrue. "The financial situation for this year will look quite different," he says. "I'm confident we can balance the books this year and next."

The three PLoS journals that launched last year - PLoS Computational Biology, PLoS Genetics and PLOS Pathogens - are run by vol-

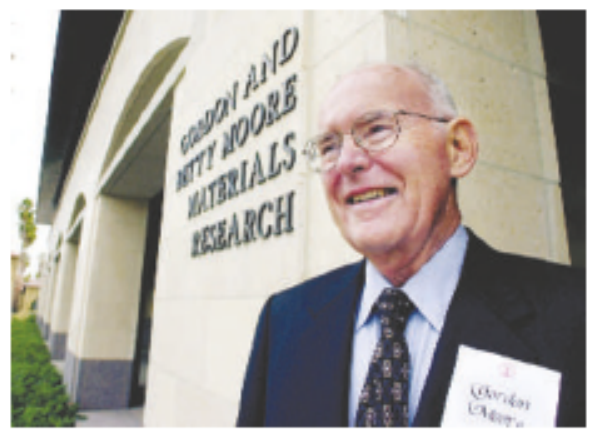

Gordon Moore's philanthropic foundation has donated $\$ 9$ million to the PLoS publishing effort. unteer academic editorial teams, rather than in-house staff. This should help to ease the pressure on finances overall, explains Patterson, as they have lower editorial costs and are more likely to break even than PLoS Biology and PLOS Medicine.

In a further move towards highvolume publishing, PLoSintends to launch an open-access online database, called PLoS One, later this year. Papers published on the database will be peer reviewed only to check that they are technically sound, and not to assess novelty. The resource will publish "hundreds of papers per month", says Chris Surridge, its Cambridge-based managing editor, and pay for itself through fees and economies of scale.

The diversification should help PLoS balance its books, agrees Matthew Cockerill, publisher of BioMed Central, a London-based open-access publisher. The high cost and low volume of articles in PLoS's flagship journals mean " they are not by themselves financially sustainable in isolation", he argues.

BioMed Central, which last July increased its charges from $\$ 500$ to as much as $\$ 1,700$, depending on the journal, has also yet to break even. It is "getting close", says Cockerill, who declined to give an estimate of when breakeven would occur: " Predicting the future is not a wise activity to engage in."

The hike in PLoS's fees, announced earlier this month, is due to take effect from 1 July. It is similarly intended to improve the firm's financial position by "reflecting more closely the costs of publication", according to a statement on the PLoS website announcing the increases. Author charges will rise to $\$ 2,500$ for PLOS Biology, PLOS Medicine and PLoS Clinical Trials and to $\$ 2,000$ for PLoS Computational Biology, PLaS Genetics and PLOS Pathogens.

When PLoS launched, other publishers expressed scepticism over its sustainability, arguing that the $\$ 1,500$ fee was unrealistically : low for covering the costs of producing a highquality journal (see Nature 425, 554-555; 2003). PLoS rejected this argument as coming from journals with a vested interest in maintaining the reader-pays status quo. It said the $\$ 1,500$ figure was realistic and was based on a business plan thrashed out with publishing experts. "Four years further on, we know a lot more," says Patterson.

Declan Butler 